Article

\title{
Migration of Barchan Dunes in Qatar-Controls of the Shamal, Teleconnections, Sea-Level Changes and Human Impact
}

\author{
Max Engel ${ }^{1, *(1)}$, Fabian Boesl ${ }^{2}$ and Helmut Brückner ${ }^{2}$ \\ 1 Royal Belgian Institute of Natural Sciences, OD Earth and History of Life, Geological Survey of Belgium, \\ Jennerstraat 13, 1000 Brussels, Belgium \\ 2 University of Cologne, Institute of Geography, Zülpicher Str. 45, 50674 Cologne, Germany; \\ fabian.boesl@gmx.de (F.B.); h.brueckner@uni-koeln.de (H.B.) \\ * Correspondence: max.engel@naturalsciences.be
}

Received: 29 April 2018; Accepted: 22 June 2018; Published: 29 June 2018

\begin{abstract}
Barchan dune fields are a dominant landscape feature in SE Qatar and a key element of the peninsula's geodiversity. The migration of barchan dunes is mainly controlled by dune size, wind patterns, vegetation cover and human impact. We investigate the variability of dune migration in Qatar over a time period of 50 years using high-resolution satellite and aerial imagery. We then explore its relation to the regional Shamal wind system, teleconnection patterns, and limitations in sand supply associated with the transgression of the Arabian Gulf. Strong size-dependent differences in migration rates of individual dunes as well as significant decadal variability on a dune-field scale are detected, which are found to correlate with the intensity of the North Atlantic Oscillation (NAO) and the Indian Summer Monsoon (ISM), in particular during years of relatively strong (weak) summer Shamals. High uncertainties associated with the extrapolation of migration rates back into the Holocene, however, do not permit further examination of the timing of the loss of sand supply and the onset of the mid-Holocene relative sea-level (RSL) highstand. For the youngest phase considered in this study (2006-2015), human impact has likely accelerated dune migration under a weakening Shamal regime through sand mining and excessive vehicle traffic upwind of the core study area.
\end{abstract}

Keywords: Aeolian geomorphology; Arabian Peninsula; Arabian/Persian Gulf; remote sensing; Holocene landscape change

\section{Introduction}

Barchan dunes are singular crescentic features with a convex side directed upwind and two horns pointing downwind. They form from small sand patches by windward deflation over a gradually developing low-angle slope, where grains eventually slide down a steeper leeward slope. This process is faster at the lower margins, resulting in the horns running ahead [1]. Barchan dunes form in areas of moderate sand supply and low variability of wind direction [2-4]. Slight variations of wind direction may result in a single horn extension or even the transformation to linear dunes [5]. Barchan dynamics are complex and their migration is a function of shear stress and, more pragmatically, closely related to wind velocity [2]. Barchans represent excellent recorders of wind pattern changes [6], even though the secondary, micro-scale air flow regime [2] and dune height play a role as well. Based on the derivate of $\mathrm{v}$ (velocity) with respect to $\mathrm{u}^{*}$ (wind shear velocity) of Bagnold's [7] equation: 


$$
\mathrm{V}=\mathrm{C} \cdot \mathrm{u}^{*} \cdot 3 / \mathrm{h}
$$

where $\mathrm{C}=$ the constant of proportionality and $\mathrm{h}=$ barchan dune height, any modification in wind speed is enhanced by a factor of three in dune velocity [6].

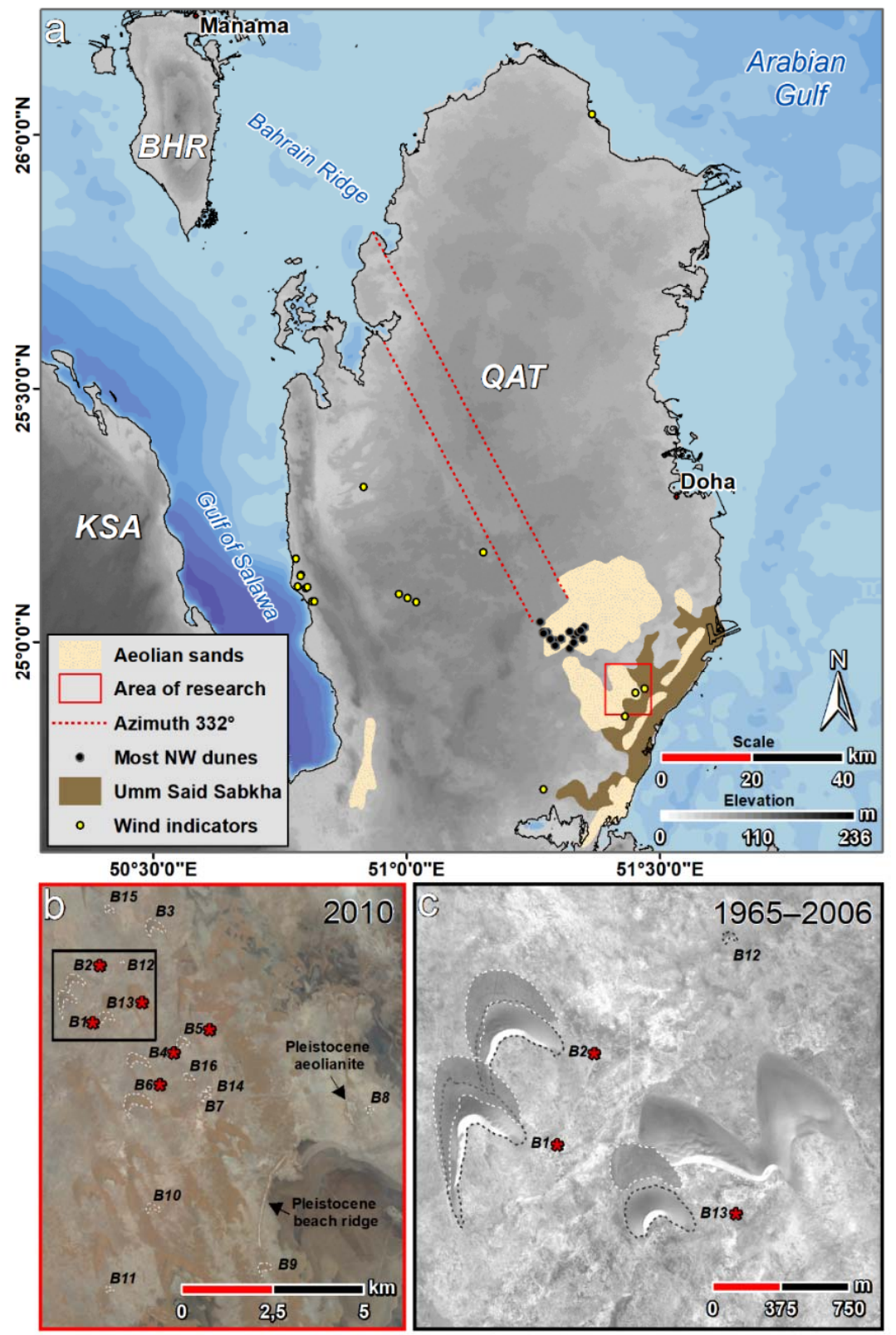

Figure 1. (a) Overview of the Qatar peninsula based on SRTM30 data [8] and the GEBCO_2014 grid [9] showing the location of the distribution of aeolian surface deposits (mostly in the form of barchanoid dunes), the core study area within the barchan dune fields, the associated downwind Umm Said sabkha, the former main sediment source areas of the shallow Bahrain Ridge and northern Gulf of Salwa, the main corridor of barchan migration in the past (azimuth $332^{\circ}$ deviation from $\mathrm{N}$ after [10]), and the distribution of long-term geomorphic indicators of Shamal predominance. The most NW dunes were used to infer the timing of the loss of sand supply; (b) Core study area with barchan dunes B1-B16 (based on Landsat-7, courtesy of the U.S. Geological Survey). Dunes mined between 2006 and 2015 are marked with red asterisk; (c) Examples of dune migration towards SSE between 1965 (Gambit KH-7) and 2006 (OrbView-3) (cf. Table 1). 
Thus, on a dune field scale, barchan dunes of different sizes may collide and merge [4]. The smallest barchan dunes may reach migration rates of 30-100 m/year [3]. Acceleration of sand grains is highest at the upper part of the gentler windward slope due to upslope streamline compression, whereas the barchan's crest marks the boundary between aeolian erosion and gravitational accumulation areas [2]. Barchan dunes respond to environmental change, as increased moisture and the establishment of vegetation may result in speed reduction or even the transformation into a stationary parabolic or blow-out dune [11].

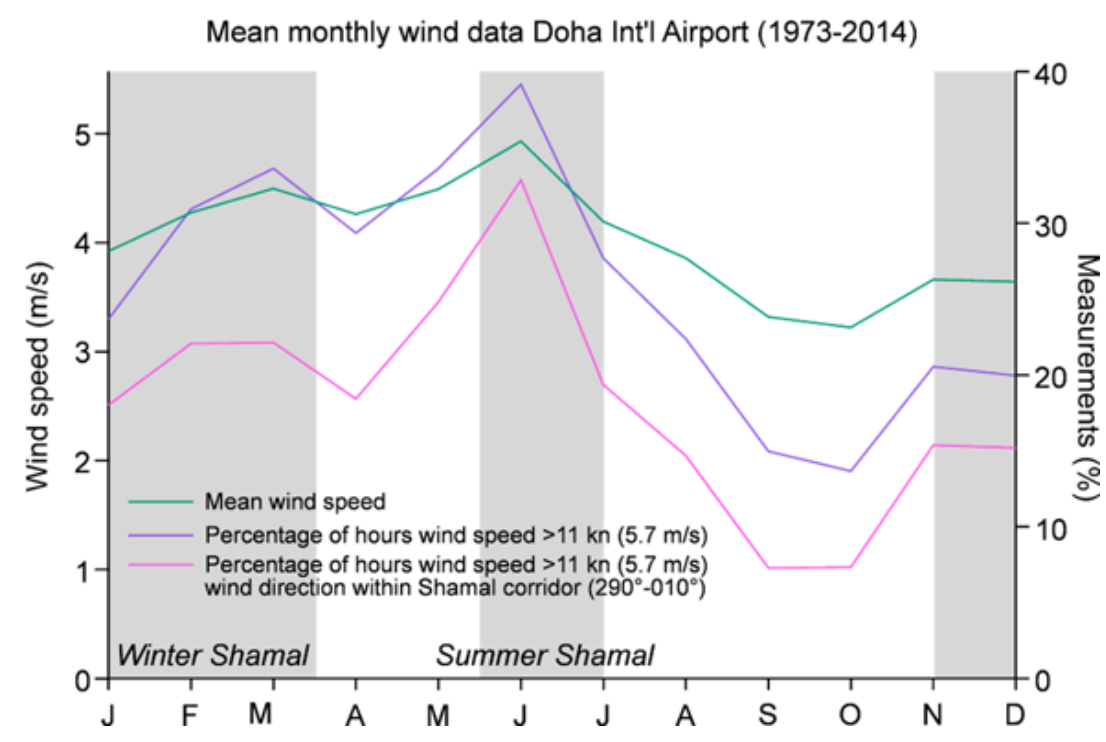

Figure 2. Monthly distribution of mean wind speed, general percentage of hours of wind speed $>11 \mathrm{kn}$, and percentage of hours of wind speed $>11 \mathrm{kn}$ within the Shamal corridor $\left(290^{\circ}-010^{\circ}\right.$ deviation from N) at Doha International Airport [12], the longest serving climate station in Qatar.

Interpolating migration rates from multi-year or even decadal observations is challenging since small dunes may separate from the horns of larger ones [13] and the size of barchans fluctuates over time [4]. Size changes are determined by the difference between upwind sand supply and efflux from the horns, which is a function of horn width [14]. However, on a dune-field scale and in the long term, the size of barchans is considered to stay rather stable $[2,15]$, and therefore, fluctuations in dune swarm migration over larger time-scales may be closely related to external factors, mostly changing wind patterns or changes in vegetation cover.

In Qatar, remnant barchan dunes occur mostly in the SE and are assumed to have travelled over the entire peninsula from the NW, driven by the regional Shamal wind regime (Figure 1). Their absence in most parts of Qatar today has been related to rapid post-glacial flooding of the shallow Arabian Gulf starting at around 14,000 years ago, when mobile sand dunes covered almost the entire floor of the Gulf. At the time when present sea level was reached, shortly before the regional highstand of c. $+2 \mathrm{~m}$, sand sources in the wider area of the Bahrain Ridge were drowned. As a result, it is suggested that sand supply stopped and large parts of the peninsula gradually became free of dunes [16-18]. The exact timing of the loss of sand supply, however, is largely unclear. Rough estimates of 8000-6000 years ago [19,20], 10,000-8000 years ago [21], or even 12,000 years ago [22] can be found in literature, along with the rather precise timing of 4100 years ago [10]. Likewise, a broad range of dates is found for the mid-Holocene sea-level highstand both in Qatar and the wider Gulf region, e.g., 8000-4000 years ago [23], 5 to 6 millennia ago [24], 6000-4500 cal years BP [25], around 6000 BP [18], 5000-3500 cal years BP [26], or "shortly after 5290-4570 cal year BP" [27] (p. 79).

In this paper, we provide a precise 50-year record of barchan dune migration in Qatar and analyze the driving mechanisms. Understanding the long-term migration of the peninsula's dunes is important, 
as (i) their mobility imposes a hazard on built infrastructure as well as the developing agricultural sector [28], and (ii) they represent a key element of the peninsula's geodiversity with an important function for leisure and tourism. We discuss the influence of variability in global circulation patterns on Shamal activity and dune mobility. In a further step, we compare extrapolated migration rates with the loss of the sand source after flooding of the Bahrain Ridge and the Gulf of Salwa, and try to provide more precise chronological constraints. In a last step, a qualitative evaluation is given of how human impact through sand mining and excessive vehicle traffic influences barchan dune dynamics in Qatar.

\section{Study Area}

\subsection{The Physical Setting and Wind Pattern of Qatar}

The Qatar peninsula is an anticlinal structure of uplifted Tertiary limestone, dolomite, marl, chalk and shale formations protruding into the Arabian Gulf. Today's low to moderate relief is formed by the Lower and Middle Eocene Rus and Dammam formations representing shallow marine carbonates with intercalated anhydrites [29,30]. Tectonic uplift and slight folding since then resulted in the emergence of Qatar, its continental conditions, and a shortage of sediments from subsequent stages and series. Miocene sedimentary rocks are mainly found in southern Qatar, represented by shallow marine limestones, gypsum, dolomite, and mudstone of the Dam Formation, as well as the continental Hofuf conglomerates. The topography is rather flat; notable rises only occur in the south [29].

The climate of Qatar is arid, though relative humidity may rise up to $90 \%$. The annual precipitation ranges between $50-80 \mathrm{~mm}$ and occurs mainly during winter and spring. However, the spatio-temporal pattern of rainfall is very irregular [10]. The wind regime is dominated by the NW to N regional Shamal winds approaching Qatar mostly during early June to mid-July and November to March, respectively [31] (Figure 2). This regional wind system mostly affects Saudi Arabia, Kuwait, and Qatar [32], and controls the movement of barchans in SE Qatar [10]. In May, the summer Shamal is mainly determined by a lower to middle tropospheric westerly trough over Iran and a corresponding ridge over Anatolia resulting in atmospheric descent over the northern Arabian Peninsula and the creation of a regional anticyclone. In combination with an established heat low over Iran, these conditions initiates short-term, multiple-day Shamal activity over Qatar [32] with surface wind speeds of up to $13 \mathrm{~m} / \mathrm{s}$ [33]. Stronger and longer-duration Shamals during June and July are controlled by a steep gradient between the Mediterranean high-pressure cell, and the regional depression over Iran and adjacent areas resulting from extreme heating of surface air masses [32,34,35]. The winter Shamal (November to March) may even reach wind speeds of 15-20 m/s over the Arabian Gulf $[35,36]$, and is usually associated with a surface low-pressure area over Syria migrating eastward towards Iran and pushing a cold front south and west. A low-pressure center along this southward moving front in the northern Arabian Gulf and a surface high-pressure cell over the northern Arabian Peninsula finally induce the winter Shamal, which is not as consistent as its summer counterpart [31]. The Shamal triggers severe dust storms, which represent a high-frequency hazard to different types of operational services (e.g., aviation) in the Gulf region [32]. The long-term persistence of dominating winds from $290^{\circ}-010^{\circ}$ is also reflected by the alignment of the main axis of nebkhas and sand drapes at prehistoric burial cairns, by micro-yardangs inside the inland sediment-filled depressions (rawdhat), or sandblasting features on rock surfaces in most parts of the peninsula (Figure 3). 

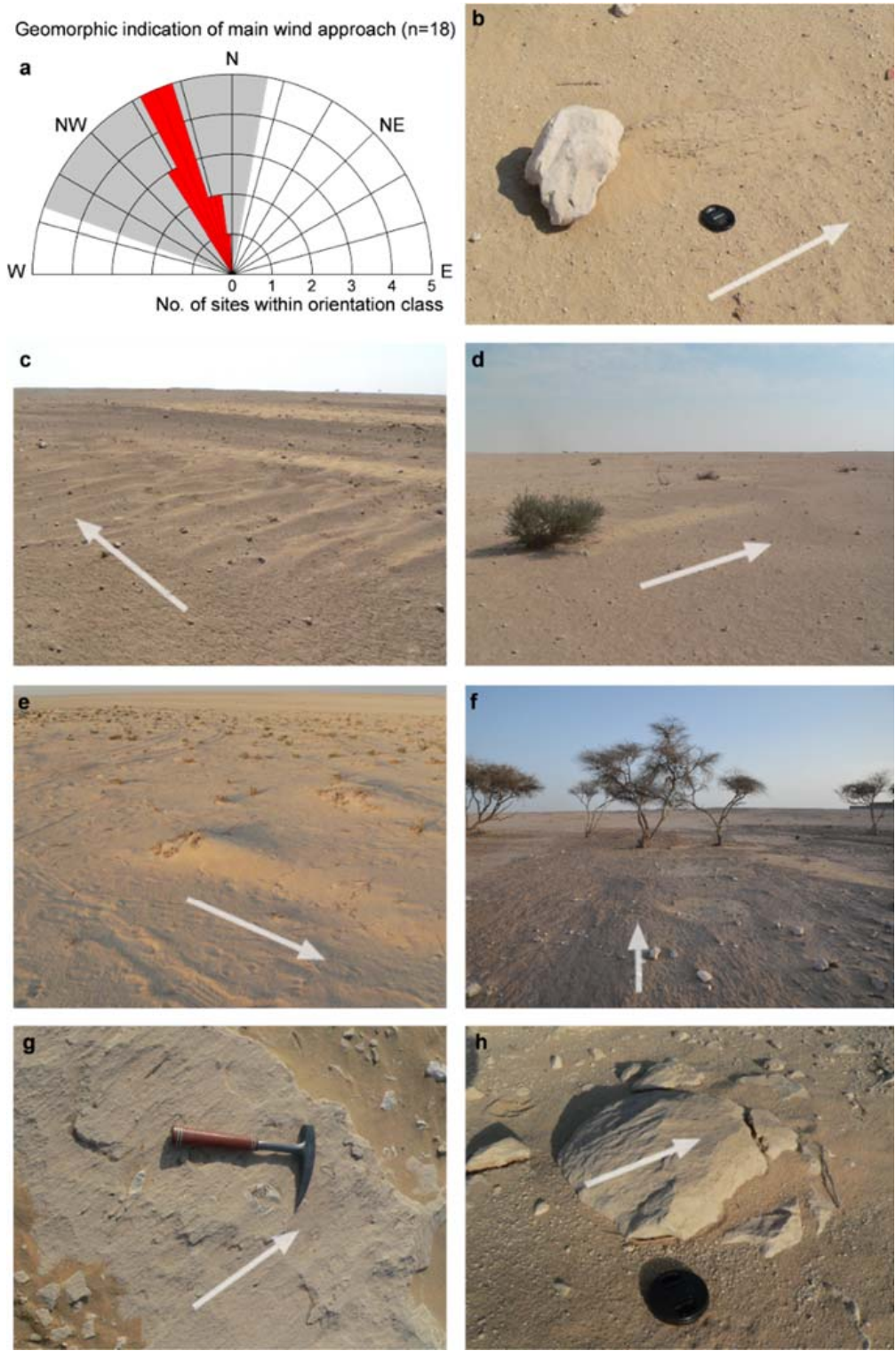

Figure 3. (a) Direction of geomorphic indicators of long-term Shamal predominance mapped during the field survey (yellow dots in Figure 1a). The wider Shamal corridor of $290^{\circ}-010^{\circ}$ is grey-shaded; (b) Micro-yardang inside a rawdha indicating deflation in these silt/sand-filled karstic depressions. Its formation is triggered by protection through a larger boulder; (c) Transversal wind ripples perpendicular to Shamal direction, c. $10 \mathrm{~cm}$ high; (d) Incipient nebkha associated with a long drape of sand developed in the lee of a shrub; (e) Small herbaceous nebkha with shorter leeward tail; (f) Linear corrasion features on a rawdha surface; (g) Linear corrasion features on a MIS 5 beachrock (see "Pleistocene beach ridge" in Figure 1b) [25]; (h) Linear corrasion features on subaerially exposed Dammam limestone. All arrows point into the downwind Shamal direction.

\subsection{Barchans of Qatar}

Barchanoid dunes cover significant parts of the ergs of the Sahara, the Takla Makan in northern China, the Pesky Karakumy of Kasakhztan and the Rub' al-Khali on the southern Arabian Peninsula [37]. In Qatar, dunes are concentrated in the SE and cover c. $10 \%$ of the entire peninsula, i.e., c. $976 \mathrm{~km}^{2}$. According to the main approaching angle of the Shamal winds, the tails of the barchans point to SSE-SE [10,29]. Embabi and Ashour [10] mapped four types of barchan dunes in SE Qatar, including (i) textbook-like simple barchans of various sizes (width across horns $=15-1000 \mathrm{~m}$ ), 
(ii) modified barchans with a longer and thinner western horn, (iii) compound barchans in transition to longitudinal dunes, and (iv) fully developed longitudinal dunes. Dune asymmetry as observed within the modified barchans is ascribed to a local SE wind component. Height reaches up to $40 \mathrm{~m}$ but is mostly less than $10 \mathrm{~m}$. The barchans mainly consist of quartz sand with minor portions of skeletal grains and argillaceous dust, as well as minute amounts of heavy mineral components. The composition of the latter, though dominated by rather cosmopolitan minerals such as almandite, zircon, tourmaline, sphene, or rutile, permits us to locate its source on the Arabian Shield. Sands are unimodal and peak in fine to medium classes. Grains are generally rounded to subrounded [10]. Barchan dunes covering the floor of the shallow Gulf of Salwa have also been identified on Landsat imagery [21].

\section{Materials and Methods}

In a first step, the migration was recorded for 16 individual barchan dunes (B1-B16) of type (i) and (ii) sensu Embabi and Ashour [10] by multitemporal analysis of high-resolution satellite and aerial images. The study area was defined based on the availability of satellite scenes, and the presence and traceability of barchan dunes. The multitemporal analyses included Gambit KH-7 (1965), Hexagon KH-9 (1978), a resampled aerial ortho-mosaic (1995), OrbView-3 (2006), and SPOT 7 (2015) data (Table 1). While the Hexagon imagery, was eventually discarded due to insufficient resolution, individual dunes became lost for the analysis on the SPOT imagery due to extensive mining activities after 2006 (Figure 4). All scenes were rectified using an IKONOS mosaic of 2004 and 40-60 reference points by spline transformation/interpolation in ArcGIS. The IKONOS scene uses the local coordinate reference system QND95 and is projected on the Qatar National Grid. Some of the few persistent reference features are provided by Pleistocene aeolianite and beachrock in an otherwise highly dynamic landscape (Figure 1b).

The migration was defined as the average displacement of five different reference points on the dune per number of months in between two images: the intersection of the crest as well as the windward and leeward boundaries with the centerline axis, and the tips of both horns (Figure 5). This type of manual measurement of dune migration for high-resolution imagery in the range of $1 \mathrm{~m} /$ pixel has provided reliable results comparable to those from the application of automated tools of subpixel correlation of satellite imagery, such as COSI-Corr [6].

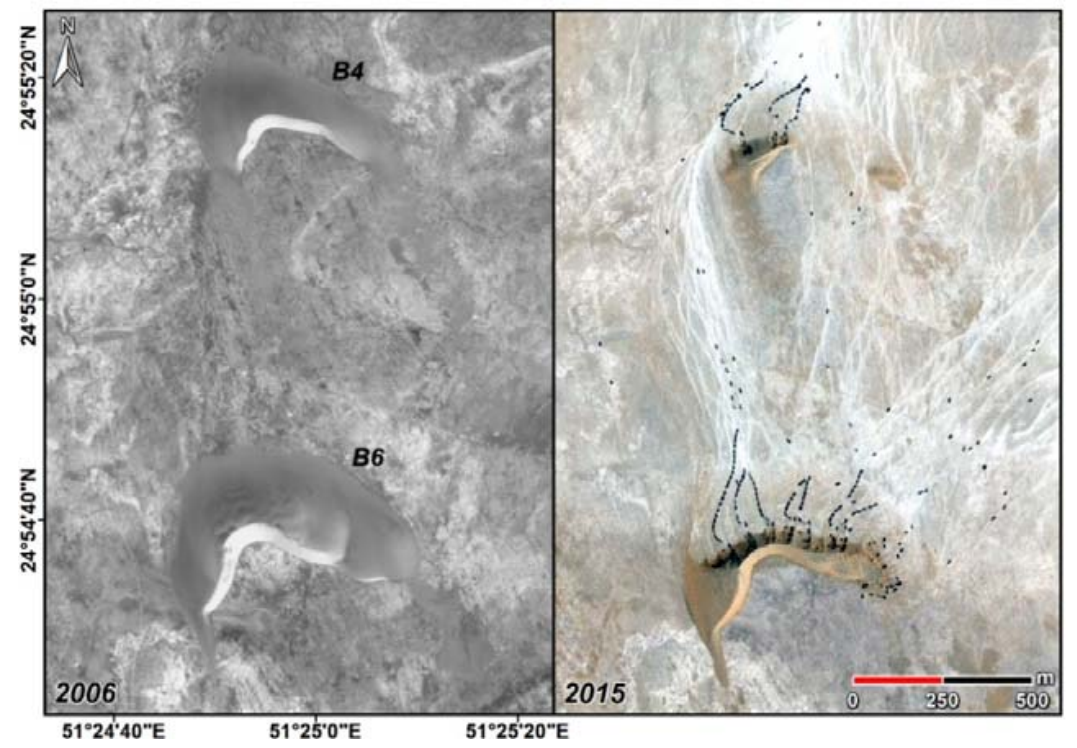

Figure 4. Documentation of sand mining at two dunes of the core study area between 2006 and 2015, as well as associated massive traffic of $>100$ heavy trucks at a time, which access the NW part of the core study area from the upwind corridor. 
Table 1. Imagery used in this study.

\begin{tabular}{cccc}
\hline Mission & Date & Resolution & Remarks \\
\hline Gambit (KH-7) & 4 November 1965 & c. $0.6-1.2 \mathrm{~m} /$ pixel & $0.8 \mathrm{~m} /$ pixel in the used scene \\
Aerial ortho-mosaic & February 1995 & $1 \mathrm{~m} /$ pixel & Sampled to $1 \mathrm{~m} /$ pixel \\
IKONOS & 2004 & $1 \mathrm{~m} /$ pixel & First commercial satellite to reach $1 \mathrm{~m} /$ pixel; color (only for georeferencing) \\
OrbView-3 & 4 March 2006 & c. $1 \mathrm{~m} /$ pixel & $1 \mathrm{~m} /$ pixel in the used scene \\
SPOT 7 & 4 May 2015 & c. $1.5 \mathrm{~m} /$ pixel & $1.7 \mathrm{~m} /$ pixel in the used scene, color \\
\hline
\end{tabular}

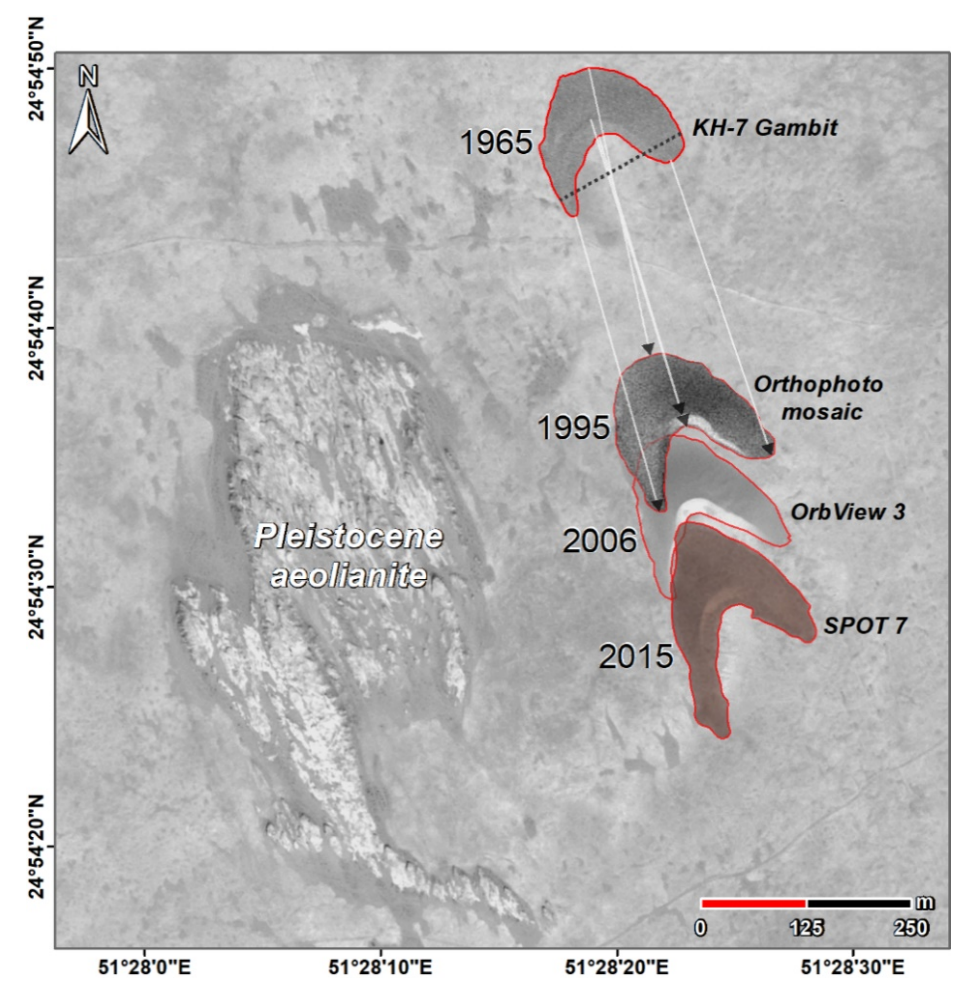

Figure 5. Approach of multitemporal satellite and aerial image analysis exemplified for barchan dune B8 (Figure 1b). Between 1965 and 2015, the entire barchan moved for ca. $587 \mathrm{~m}$ towards SSE (average value).

The width across both horns is the main size measure used in this paper based on the linear relationship between dune height and horn-to-horn width $[5,10,15]$. Considering their dataset from Qatar, Embabi and Ashour [10] express this relationship as

$$
\mathrm{W}=42.0+16.7 \cdot \mathrm{h},
$$

where $\mathrm{W}=$ horn-to-horn width, and $\mathrm{h}=$ height of the barchan crest $\left(R^{2}=0.8\right)$.

Furthermore, dune size for all four relevant time steps was measured from polygons (Figure 5) in order to investigate the effect of size changes on the variation of migration rates. The influence of bottom moisture on the migration rate was tested by comparison of additional four pairs of barchan dunes of similar sizes, each pair comprising one dune from the Umm Said sabkha with very shallow, fluctuating groundwater levels of only a few tens of $\mathrm{cm}$ below surface [29], and one travelling over entirely dry Dammam limestone.

In order to estimate the time when the Bahrain Ridge and the Gulf of Salwa became flooded, current relative sea level was reached, and the sand source became cut off, we measured travel times of the 15 barchan dunes within the width range 100-500 m closest to the NW coast ( $<80 \mathrm{~km}$ ) ("Most NW dunes" in Figure 1a). The distance to the NW coast was measured in the main Shamal azimuth of $332^{\circ}$ deviation from $\mathrm{N}$ [10], while individual, size-dependent migration velocities were derived from 
the regression function of our empirical dataset established in the first step (Equation (4)). Individual travel times of the barchan dunes from today's shoreline to their present position were transformed into a probability density function (PDF). In order to account for the variability of Shamal intensity, wind direction or other governing parameters, a tentative error of $\pm 10 \%$ and a normal probability distribution were assumed for each travel time value (=mean value), from which probabilities for additional 20 time values in $1 \%$ steps starting from the mean value were derived $(-10 \%$ to $+10 \%)$, resulting in 315 data points in total. Binning of the time axis starts at $x_{0}=100$ and follows the equation

$$
\mathrm{X}=\mathrm{x}_{0}+\mathrm{x}_{0} / 100
$$

\section{Results}

\subsection{Barchan Migration}

The migration rate of the 16 investigated barchan dunes between 1965 and 2006 varies greatly (Figure 6a) ranging from $177 \mathrm{~m}$ for a width of $580 \mathrm{~m}$ to $951 \mathrm{~m}$ (B1) for a width of $74 \mathrm{~m}$ (B12). A significant inverse power-law relationship with $R^{2}=0.86$ can be stated for the size-distance distribution following the function

$$
\ln (\mathrm{Y})=-1.12 \cdot \ln (\mathrm{X})+5.23,
$$

where $\mathrm{Y}=$ horn-to-horn width $(\mathrm{m})$ and $\mathrm{X}=$ migration distance per month $(\mathrm{m})$. Migration rates in relation to dune size derived by Embabi and Ashour [10] for the Nigyan Abu-Qatabatin dune field and Umm Said sabkha are mostly in line with these results, but show larger deviations. Some small- to medium-sized dunes from Umm Said show unusually high migration rates of $2.5 \mathrm{~m} / \mathrm{month}$ and above [10]. It is, however, difficult to determine whether the stronger variability in migration rates of this dataset compared to the results of the present study is due to reduced size-dependency, the short time frame of investigation of only a few years, which increases measurement errors while extrapolating, or the quality of the aerial imagery used in [10].
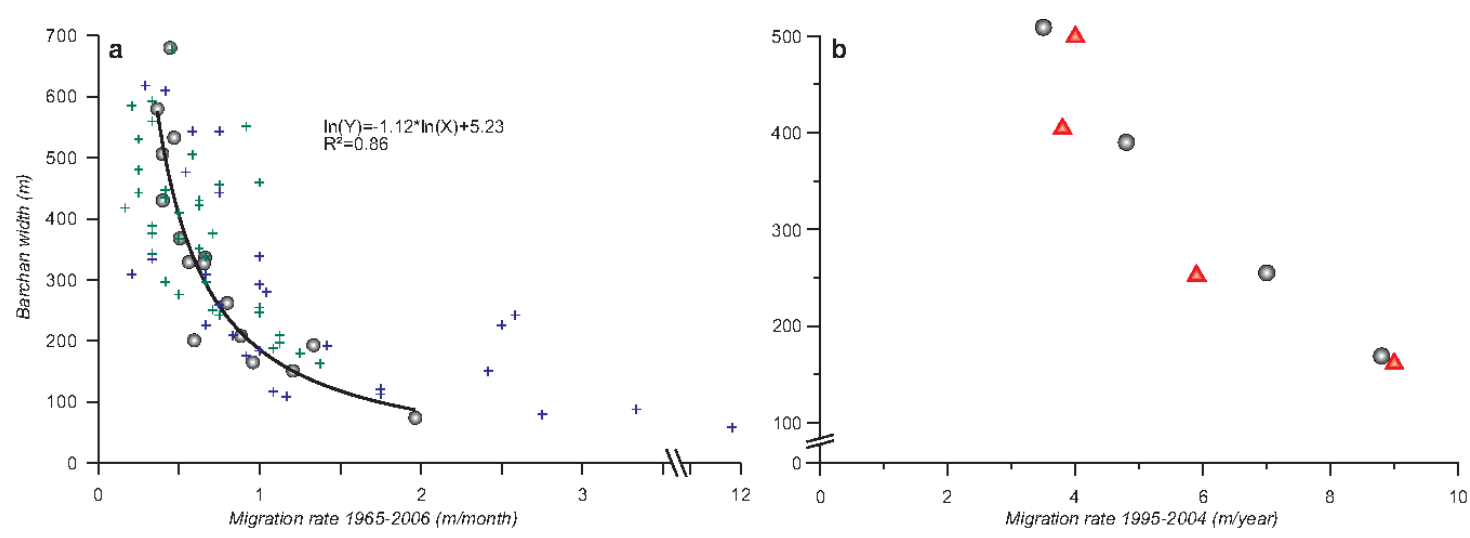

Figure 6. (a) Relationship between size of barchan dunes B1-B16 and migration rate over the time period 1965-2006 (circles), which is best explained by an inverse power-law function $\left(R^{2}=0.86\right)$. For comparison, results of Embabi and Ashour [10] derived for Umm Said sabkha (1971-1976; blue crosses) and Nigyan Abu-Qatabatin (1973-1976; green crosses) are plotted. Heights given in the original source [10] were translated into horn-to-horn width using Equation (2); (b) Comparison of migration rates between pairs of similarly sized dunes migrating over dry Dammam limestone surface (circles) and moist sabkha surface (triangles).

Only slight changes in dune size were detected on a dune field scale (Figure 7). By averaging all dunes still intact in 2015, dune size marginally increases from $0.0353 \mathrm{~km}^{2}$ in $1965,0.0367 \mathrm{~km}^{2}$ (1995) and $0.0372 \mathrm{~km}^{2}$ (2006) to $0.0381 \mathrm{~km}^{2}(2015)$. 
In order to investigate whether surface moisture has an influence on migration rates, pairs of dunes of similar size travelling either over dry Dammam limestone or the Umm Said sabkha with a groundwater table of only a few tens of $\mathrm{cm}$ [29] were compared (Figure 6b). While the smallest pair of barchan dunes travelled at similar speeds, the two medium-sized dunes show slightly faster rates on dry ground. When comparing the largest dunes of the sample, the one inside the sabkha migrates faster. In general, no clear pattern can be observed.

The highest dune migration rates were inferred for the time window 1965-1995, ranging from $0.4 \mathrm{~m} /$ month (B1) to $2.1 \mathrm{~m} /$ month (B12) (Figure 8). The time window 1995-2006 witnesses a significant drop without exception to migration rates of $0.3 \mathrm{~m} / \mathrm{month}$ to $1.7 \mathrm{~m} / \mathrm{month}$. Between 2006 and 2015, all dunes again experienced an increased migration rate to levels generally slightly below the period 1965-1995 (Figure 8e).

The travel times of the barchan dune population in closest proximity to the NW coast, which are assumed to coincide with the cut-off of the sand source and the onset of the mid-Holocene highstand, are deduced from Equation (4) and vary greatly (Figure 9). This large discrepancy is due to the significant size dependency of migration rates. The PDF covers the time period between 3300 and almost 17,000 years BP with a small gap around 10,300 years BP.

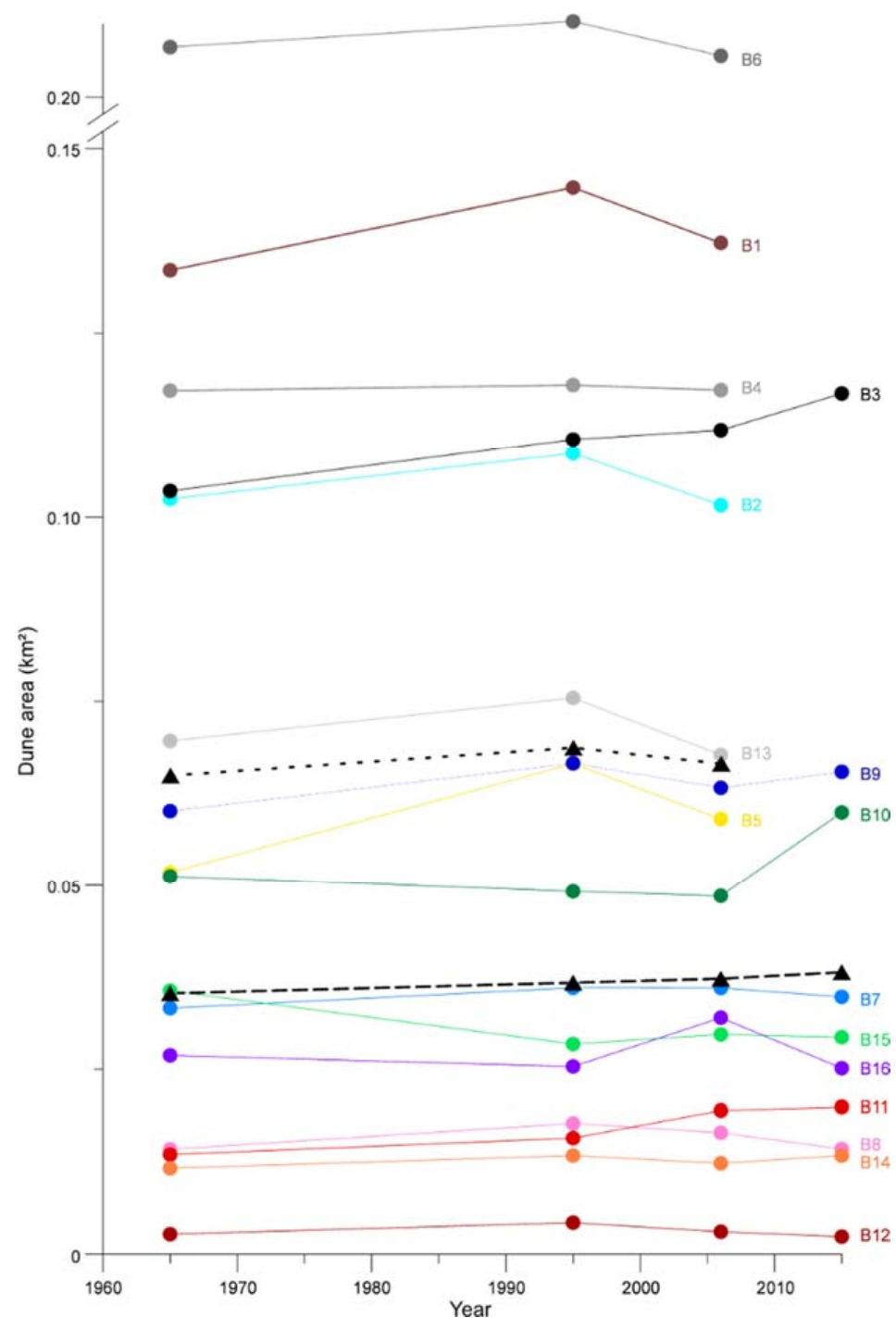

Figure 7. Changes in dune area over time. The black dotted line represents the average of all dunes B1-B16, while the dashed line shows the average of only those dunes still entirely intact in 2015. 

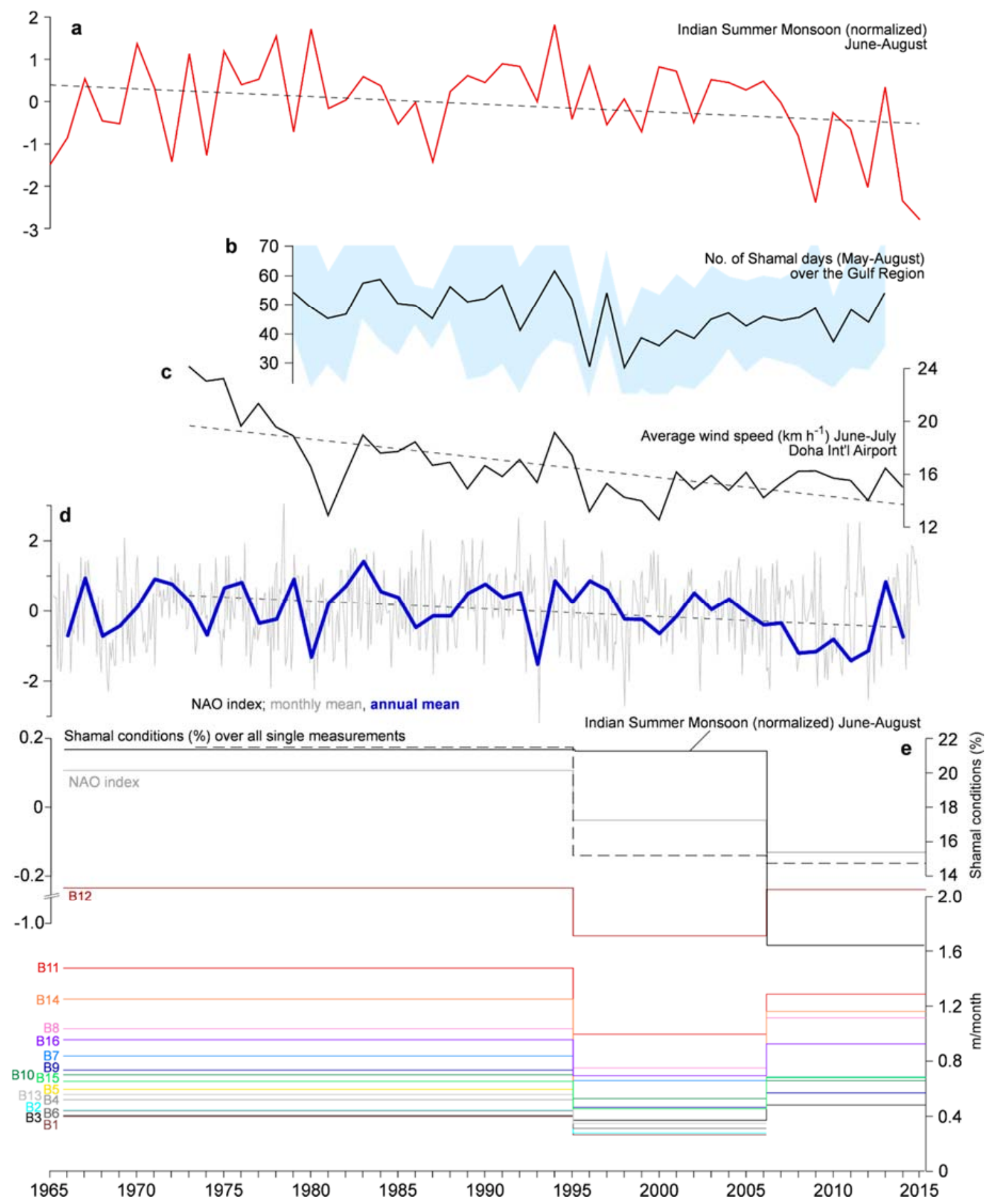

Figure 8. (a) Index of Indian Summer Monsoon (ISM) intensity between June and August after Wang and Fan [38] with dashed linear trend line; (b) Number of annual Shamal days between May and August over the entire Gulf region. The shading indicates the $\pm 1 \sigma$ standard deviation across all stations considered [35]; (c) Average wind speed in the months of June and July measured at Doha International Airport [12] with dashed linear trend line; (d) Monthly and annual mean of the North Atlantic Oscillation (NAO) index with dashed linear trend line, representing the difference between the normalized mean winter air pressure at sea level between Lisbon, Portugal (Azores High), and Stykkisholmur, Iceland (Icelandic Low) [39]; (e) ISM, NAO and the percentage of Shamal conditions in Qatar averaged over the time windows of the multitemporal satellite and aerial image analysis of barchan dune migration. These data are displayed in combination with migration rates of barchan dunes B1-B16. 


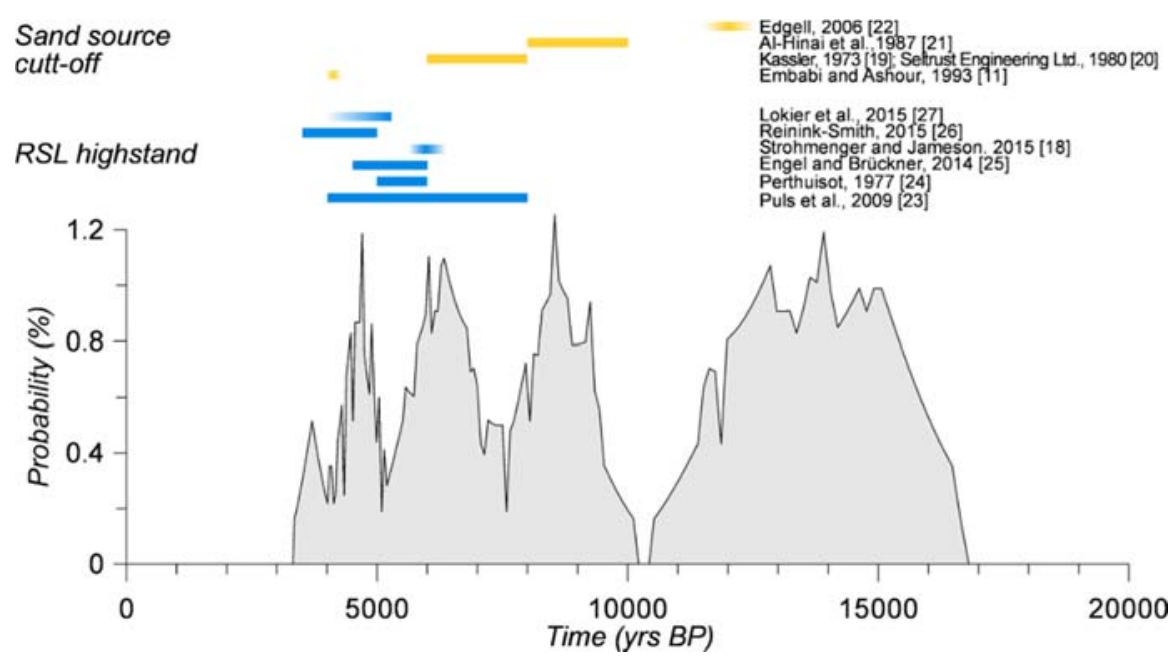

Figure 9. Probability density function of travel times of the 15 barchan dunes (width $100-500 \mathrm{~m}$ ) of SE Qatar in closest proximity to the NW coast (Figure 1a). Data are displayed in combination with chronological estimates of the relative sea-level (RSL) highstand (blue bars) and the loss of the sand source (yellow bars) as inferred from literature.

\subsection{Shamal Activity}

In terms of further mechanisms controlling barchan migration in the longer term, a significant correlation between regional (number of summer Shamal days over the Gulf region, Figure 8b) [35] and local (average wind speed June-July at Doha International Airport, Figure 8c) [12] summer Shamal activity can be observed. From the 1970s until the late 1990s, the summer Shamal constantly declined (Figure 8 b,c), while afterwards the local average wind speed in June-July fluctuates around a value of $15 \mathrm{~km} / \mathrm{h}$ [12] and the regional record even shows a moderate increase in the number of Shamal days [35]. If considering the time windows of the multitemporal satellite image analysis of barchan dune migration, the duration of Shamal conditions has initially dropped significantly from $21.5 \%$ (1973-1995) to 15.2\% (1995-2006), followed by a very similar value (14.8\%) from 2006 to 2015 (Figure 8e). The positive relationship between the North Atlantic Oscillation (NAO) and the local Shamal activity, however, is evident over the longer term, as the intensity of the NAO also declined over the last decades. In particular, years of positive or negative summer Shamal extremes in Qatar, such as in 1980/1981, 1983, 1993, 2000, or 2013, show the NAO dependency (Figure 8c,d). Likewise, it seems that the intensity of the Indian Summer Monsoon (ISM) reveals similarities with Shamal activity during comparably strong (or weak) Shamal years, such as 1994 and 2015 (or the calmer Shamal phase after 1995) (Figure 8a).

\section{Discussion}

\subsection{Barchan Dynamics and Their Control}

The multitemporal analysis of satellite and aerial imagery revealed the well-established pattern of size-dependent migration rates of barchan dunes [14,15]. Even though average dune size in our sample varied only marginally (Figure 7) and seems not to have affected variability in migration rates, it may vary significantly over larger time scales $[4,13]$, potentially leading to uncertainty when extrapolating short-term rates.

On a dune-field scale, Shamal activity is the main control of barchan migration in Qatar, as shown by remote sensing data from 1965-2006. Surface moisture variability is considered negligible based on investigation of the sabkha/non-sabkha couplets. As it coincides with driest conditions over the year, the summer Shamal is most efficient in terms of aeolian particle transport in the Middle East [36,40]. 
The influence of teleconnection patterns on the summer Shamal activity is evident from paralleling wiggles between the NAO index and average wind speed measured at Doha International Airport.

This relationship may be explained by the NAO controlling the intensity of the summer season stationary high-pressure cell over the Eastern Mediterranean [41]. The Shamal is induced by a steep gradient between the Mediterranean high-pressure cell and the depression associated with the ISM located over NW India, Iran, Iraq, Pakistan, and Afghanistan [36,42,43]. This low-pressure area usually forms in May and emanates from intense surface heating. It is closely associated with both the upper level mid-latitude circulation over western central Asia and low-level monsoonal circulation over the Arabian Sea and the Indian subcontinent [42,44]. The NAO interaction with the Middle Eastern climate goes beyond the influence on Shamal patterns, as it is also associated with the intensity of winter precipitation and streamflow in Mesopotamia [45].

Records integrating larger parts of the Gulf area, however, even show a very moderate increase of summer Shamal activity after the late 1990s [35,36], instead of a quasi-continuous trend inferred from wind intensity at Doha. Thus, even though NAO and ISM show good correlation with summer Shamal intensity in those years strongly deviating from the average (e.g., 1980/1981, 1983, 1993, 2000, 2013), their indices alone, of course, cannot explain this regional wind phenomenon entirely.

During the period 2006-2015, the pattern of dune migration significantly deviates, i.e., a speed increase is accompanied by a weakening ISM and NAO, and a rather stable summer Shamal (Figure 8e). As different varieties of human impact can have tremendous influence on dune mobility-mostly through interaction with vegetation [34,46] —we hypothesize that the intense sand mining activities in the NW part of the core study area since 2007 by the Qatar Primary Materials Company (QPMC) [47] have changed the local wind field and significantly increased sand flux, in particular in the lower range of the dune-forming grain-size spectrum. Both massive truck traffic upwind of the core study area (Figure 5) [48] and the sand mining process itself are assumed to have strongly stimulated sand flux, which is correlated to downwind barchan dune velocity [6,7]. Furthermore, reduced dune density in a dune field - in this case through sand mining — increases wind velocity, and thus, dune migration rates [10].

\subsection{Long-Term Perspective on Shamal Controls}

The NAO and the ISM have been active over the entire Holocene to support the Shamal and dune migration over the Qatar peninsula, even though both mechanisms show a gradual weakening trend over the Holocene in response to solar insolation [49,50]. In their exhaustive analysis on Quaternary stratigraphy and environments of the Arabian Peninsula, Glennie and Singhvi [51] confirm the long-term persistence of the Shamal, but state a generally weaker intensity during interglacials. While decreasing trends of the NAO and the ISM may indicate a Shamal stronger than today over most of the Holocene, and hence, higher migration rates, wetter conditions during the early to mid-Holocene transition identified in many parts of the Arabian Peninsula [50,52-54] may have stimulated vegetation cover slowing down sand flux and migration speed $[4,11,55,56]$. The ways in which these competing mechanisms have led to deviations from the migration rates identified in the shorter term multitemporal satellite and aerial image analysis of this study over millennial time scales remain a matter of speculation.

\subsection{Barchan Migration, Sediment Supply and Relative Sea-Level Change}

Due to the large size-dependent differences in migration rates of the most NW dunes, the PDF of inferred travel times shows a very broad distribution, ranging from c. 3300 to 17,000 years BP. Neither does this result conflict with any of the chronological estimates for the mid-Holocene RSL highstand and the loss of the sediment source (Figure 9), nor, unfortunately, does it add more precision to the debate. It can be stated, however, that the loss of the sand source associated with the transgression of the Gulf is to be chronologically located near the younger end of the PDF distribution, most likely between 8000-6000 years BP, as estimated by Kassler [19] and Seltrust Engineering Ltd. [20]. Taking into 
account the range of estimates for the mid-Holocene RSL highstand with the highest overlap between the different sources (c. 6000-4000 years BP, Figure 9) as well as the entire curve of post-glacial sea-level change as predicted by Lambeck [17], the estimates of 10,000-8000 years BP [21] and 12,000 years BP [22] appear too early, as much of the very shallow wider Bahrain Ridge area ( $<7 \mathrm{~m}$ water depth [57]) was still exposed at that time. The estimate of 4100 years BP [10], however, is too young, as it post-dates the vast majority of known index points of the RSL highstand along the southern coast of the Arabian Gulf $[18,25,27]$. Inferences from the analysis of Embabi and Ashour [10] might have been biased by the very short time windows of available imagery and the overrepresentation of very small barchan dunes in the sample.

\section{Conclusions}

The Shamal wind system is the main driver of barchan dune migration in Qatar. However, the distribution of the remaining major barchan dune population in the SE of the peninsula in combination with the strongly size-dependent migration rates inferred from multitemporal satellite and aerial image analysis neither provide more precise estimates on the timing of the sand source loss nor do they interfere with the established hypothesis of a RSL-controlled sediment supply.

It is suggested that the barchan-moving Shamal correlates with two major modules of the global atmospheric circulation, i.e., the North Atlantic Oscillation (NAO) and the Indian Summer Monsoon (ISM), in particular during years where Shamal intensity strongly deviates from the average. Both systems, though fluctuating, were clearly established over Holocene time scales [46,47], and so was the Shamal [48].

The correlation between Shamal activity and the velocity of barchan dunes appears disturbed after the onset of sand mining in the core study area in 2007. We hypothesize that excessive truck traffic upwind and sand loading at the mined barchan dunes strongly increased sand flux and, in combination with reduced dune density, increased downwind migration velocity, representing a rather dramatic example of human interference with the dynamics of dune systems. According to past and present migration rates, the iconic barchan dune landscape of Qatar will probably still be present for at least 2000-3000 years if the underlying driving factors do not deviate significantly. However, it seems that the size of this important geo-heritage will shrink much faster due to human activity-directly through sand mining, and indirectly through strongly increased migration rates-leading to faster calving into the shallow waters off the SE coast of Qatar, where the sand feeds the extensive Umm Said coastal sabkha system.

Author Contributions: M.E. conceived and designed the study; F.B. performed the investigations on satellite imagery; all authors analyzed the data; M.E. wrote the manuscript; all authors commented on and approved the manuscript.

Acknowledgments: Funding of fieldwork—conducted in the framework of the South Qatar Survey Project (SQSP) (https:/ / fallback.dainst.org/projekt/- / project-display/612902)—and logistic support by Qatar Museums (QM) and the Orient Department of the German Archaeological Institute (DAI) is gratefully acknowledged. Permissions for the field survey were issued by QM. Gambit, Hexagon, IKONOS and aerial ortho-imagery were kindly provided by QM, DAI and the Qatar National Historic Environment Record Project (QNHER). Additional funding of personnel costs and commercial satellite imagery was provided through a Max Delbrück Prize, junior category (Zukunftskonzept Universität zu Köln, DFG ZUK 81/1), awarded to M.E.

Conflicts of Interest: The authors declare no conflict of interest.

\section{References}

1. Besler, H. Eine Wanderdüne als Soliton? Phys. Bl. 1997, 53, 983-985. [CrossRef]

2. Livingstone, I.; Wiggs, G.F.S.; Weaver, C.M. Geomorphology of desert sand dunes: A review of recent progress. Earth Sci. Rev. 2007, 80, 239-257. [CrossRef]

3. Parteli, E.J.R.; Durán, O.; Herrmann, H.J. Minimal size of a barchan dune. Phys. Rev. E 2007, 75, 011301. [CrossRef] [PubMed] 
4. Wiggs, G.F.S. Dune morphology and dynamics. In Treatise in Geomorphology, Vol. 11: Aeolian Geomorphology; Lancaster, N., Sherman, D.J., Baas, A.C.W., Eds.; Academic Press: London, UK, 2013; pp. 201-218.

5. Hesp, P.A.; Hastings, K. Width, height and slope relationships and aerodynamic maintenance of barchans. Geomorphology 1998, 22, 193-204. [CrossRef]

6. Vermeesch, P.; Leprince, S. A 45-year time series of dune mobility indicating constant windiness over the central Sahara. Geophys. Res. Lett. 2012, 39, L14401. [CrossRef]

7. Bagnold, R.A. The Physics of Blown Sand and Desert Dunes; Methuen: London, UK, 1941.

8. Farr, T.G.; Rosen, P.A.; Caro, E.; Crippen, R.; Duren, R.; Hensley, S.; Kobrick, M.; Paller, M.; Rodriguez, E.; Roth, L.; et al. The Shuttle Radar Topography Mission. Rev. Geophys. 2007, 45, RG2004. [CrossRef]

9. Weatherall, P.; Marks, K.M.; Jakobsson, M.; Schmitt, T.; Tani, S.; Arndt, J.E.; Rovere, M.; Chayes, D.; Ferrini, V.; Wigley, R. A new digital bathymetric model of the world's oceans. Earth Space Sci. 2015, 2, 331-345. [CrossRef]

10. Embabi, N.S.; Ashour, M.M. Barchan dunes in Qatar. J. Arid Environ. 1993, 25, 49-69. [CrossRef]

11. Bubenzer, O.; Besler, H. Sands as Archives of Environmental Change: Examples from Egypt, Sudan and Namibia. In Towards Interdisciplinarity_Experiences of the Long-Term ACACIA Project; Möhlig, W.J.G., Bubenzer, O., Menz, G., Eds.; Rüdiger Köppe Verlag: Cologne, Germany, 2010; pp. 23-48.

12. NCDC (National Climate Data Center). NOAA NCDC Climate Data Online. Available online: https:/ / www7.ncdc.noaa.gov/CDO/ (accessed on 12 November 2017).

13. Anderson, R.S. The attraction of sand dunes. Nature 1996, 379, 24-25. [CrossRef]

14. Hersen, P.; Andersen, K.H.; Elbelrhiti, H.; Andreotti, B.; Claudin, P.; Douady, S. Corridors of barchan dunes: Stability and size selection. Phys. Rev. E 2004, 69, 011304. [CrossRef] [PubMed]

15. Hesse, R. Do swarms of migrating barchan dunes record paleoenvironmental changes?-A case study spanning the middle to late Holocene in the Pampa de Jaguay, southern Peru. Geomorphology 2009, 104, 185-190. [CrossRef]

16. Shinn, E.A. Carbonate coastal accretion in the area of longshore transport, NE Qatar. In The Persian Gulf: Holocene Carbonate Sedimentation and Diagenesis in a Shallow Epicontinental Sea; Purser, B.H., Ed.; Springer: Berlin, Germany, 1973; pp. 179-191.

17. Lambeck, K. Shoreline reconstructions for the Persian Gulf since the Last Glacial Maximum. Earth Planet. Sci. Lett. 1996, 142, 43-57. [CrossRef]

18. Strohmenger, C.J.; Jameson, J. Modern coastal systems of Qatar as analogues for arid climate carbonate reservoirs: Improving geological and reservoir modelling. First Break 2015, 33, 41-50. [CrossRef]

19. Kassler, P. The structural and geomorphic evolution of the Persian Gulf. In The Persian Gulf: Holocene Carbonate Sedimentation and Diagenesis in a Shallow Epicontinental Sea; Purser, B.H., Ed.; Springer: Berlin, Germany, 1973; pp. 11-32.

20. Seltrust Engineering Ltd. Qatar Geological Map, scales 1:100,000 (Four Sheets) and 1:200,000 (One Sheet) and Explanatory Booklet; IDTC: Doha, Qatar, 1980; 20p.

21. Al-Hinai, K.G.; McMahon Moore, J.; Bush, P.R. LANDSAT image enhancement study of possible submerged sand-dunes in the Arabian Gulf. Int. J. Remote Sens. 1987, 8, 251-258. [CrossRef]

22. Edgell, H.S. Arabian Deserts—Nature, Origin, and Evolution; Springer: Dordrecht, The Netherlands, 2006; pp. 187-188.

23. Puls, D.D.; Jameson, J.; Kozar, M.; Al-Ansi, H.; LeBlanc, J. The Dukhan Sabkha: A Modern Analog for the Arab C Carbonate Reservoir, Dukhan Field, Qatar. In Proceedings of the International Petroleum Technology Conference, Doha, Qatar, 7-9 December 2009; Volume 3, pp. 1799-1811. [CrossRef]

24. Perthuisot, J.P. Contribution a l'étude du Quaternaire marin de la péninsule de Qatar. Bull. Soc. Géol. Fr. 1977, 1167-1170. [CrossRef]

25. Engel, M.; Brückner, H. The South Qatar Survey Project (SQSP)—Preliminary findings on Holocene coastal changes and geoarchaeological archives. Z. Orient Archäol. 2014, 7, 290-301.

26. Reinink-Smith, L.M. AMS-dated mollusks in beach ridges and berms document Holocene sea-level and coastal changes in northeastern Kuwait Bay. Quat. Res. 2015, 87, 200-213. [CrossRef]

27. Lokier, S.W.; Bateman, M.D.; Larkin, N.R.; Rye, P.; Stewart, J.R. Late Quaternary sea-level changes of the Persian Gulf. Quat. Res. 2015, 84, 69-81. [CrossRef]

28. Sadiq, A.; Hoqari, F. Remote sensing and spectral characteristics of desert sand from Qatar Peninsula, Arabian/Persian Gulf. Remote Sens. 2009, 1, 915-933. [CrossRef] 
29. Al-Yousef, M. Mineralogy, Geochemistry and the Origin of Quaternary Sabkhas in the Qatar Peninsula, Arabian Gulf. Ph.D. Thesis, University of Southampton, Southampton, UK, 2003.

30. Al-Saad, H. Lithostratigraphy of the Middle Eocene Dammam Formation in Qatar, Arabian Gulf: Effects of sea-level fluctuations along a tidal environment. J. Asian Earth Sci. 2005, 25, 781-789. [CrossRef]

31. Rao, P.G.; Al-Sulaiti, M.; Al-Mulla, A.H. Winter shamals in Qatar, Arabian Gulf. Weather 2001, 56, 444-451. [CrossRef]

32. Rao, P.G.; Hatwar, H.R.; Al-Sulaiti, M.H.; Al-Mulla, A.H. Summer shamals over the Arabian Gulf. Weather 2003, 58, 471-478. [CrossRef]

33. Bartlett, K.S. Dust Storm Forecasting for Al Udeid AB, Qatar: An Empirical Analysis. Master's Thesis, Air University, Montgomery County, OH, USA, 2004.

34. Barth, H.-J. Characteristics of the wind regime north of Jubail, Saudi Arabia, based on high resolution wind data. J. Arid Environ. 2001, 47, 387-402. [CrossRef]

35. Yu, Y.; Notaro, M.; Kalashnikova, O.V.; Garay, M.J. Climatology of summer Shamal wind in the Middle East. J. Geophys. Res. Atmos. 2016, 121, 289-305. [CrossRef]

36. Al Senafi, F.; Anis, A. Shamals and climate variability in the Northern Arabian/Persian Gulf from 1973 to 2012. Int. J. Climatol. 2015, 35, 4509-4528. [CrossRef]

37. Breed, C.S.; Grow, T. Morphology and distribution of dunes in sand seas observed by remote sensing. Geol. Surv. Prof. Paper 1979, 1052, 253-304.

38. Wang, B.; Fan, Z. Choice of South Asian Summer Monsoon Indices. Bull. Am. Meteorol. Soc. 1999, 80, 629-638. [CrossRef]

39. NWS (National Weather Service). North Atlantic Oscillation (NAO). Available online: http:/ /www.cpc.ncep. noaa.gov/data/teledoc/nao.shtml (accessed on 16 April 2018).

40. Middleton, N.J. A geography of dust storms in Southwest Asia. Int. J. Climatol. 1986, 6, 183-196. [CrossRef]

41. Ben-Gai, T.; Bitan, A.; Manes, A.; Alpert, P.; Kushnir, Y. Temperature and surface pressure anomalies in Israel and the North Atlantic Oscillation. Theor. Appl. Climatol. 2001, 69, 171-177. [CrossRef]

42. Saeed, S.; Müller, W.A.; Hagemann, S.; Jacob, D. Circumglobal wave train and the summer monsoon over northwestern India and Pakistan: The explicit role of the surface heat low. Clim. Dyn. 2011, 37, 1045-1060. [CrossRef]

43. Hamidi, M.; Kavianpour, M.R.; Shao, Y. Synoptic analysis of dust storms in the Middle East. Asia-Pac. J. Atmos. Sci. 2013, 49, 279-286. [CrossRef]

44. Bansod, S.D.; Singh, S.V. Pre-monsoon surface pressure and summer monsoon rainfall over India. Theor. Appl. Climatol. 1995, 51, 59-66. [CrossRef]

45. Cullen, H.M.; deMenocal, P.B. North Atlantic Influence on Tigris-Euphrates Streamflow. Int. J. Climatol. 2000, 20, 853-863. [CrossRef]

46. Yizhaq, H.; Ashkenazy, Y.; Tsoar, H. Sand dune dynamics and climate change: A modeling approach. J. Geophys. Res. 2009, 114, F01023. [CrossRef]

47. Al-Ansary, M.; Pöppelreiter, M.C.; Al-Jabry, A.; Iyengar, S.R. Geological and physiochemical characterisation of construction sands in Qatar. Int. J. Sust. Built Environ. 2012, 1, 64-84. [CrossRef]

48. Gillette, D.A.; Adams, J. Accelerated Wind Erosion and Prediction of Rates. In Environmental Effects of Off-Road Vehicles; Webb, R.H., Wilshire, H.G., Eds.; Springer: New York, NY, USA, 1983; pp. 97-111.

49. Rimbu, N.; Lohmann, G.; Kim, J.-H.; Arz, H.W.; Schneider, R. Arctic/North Atlantic Oscillation signature in Holocene sea surface temperature trends as obtained from alkenone data. Geophys. Res. Lett. 2003, 30, 1280. [CrossRef]

50. Fleitmann, D.; Burns, S.J.; Mangini, A.; Mudelsee, M.; Kramers, J.; Villa, I.; Neff, U.; Al-Subbary, A.A.; Buettner, A.; Hippler, D.; et al. Holocene ITCZ and Indian monsoon dynamics recorded in stalagmites from Oman and Yemen (Socotra). Quat. Sci. Rev. 2007, 26, 170-188. [CrossRef]

51. Glennie, K.W.; Singhvi, A.K. Event stratigraphy, paleoenvironment and chronology of SE Arabian deserts. Quat. Sci. Rev. 2002, 21, 853-869. [CrossRef]

52. Parker, A.G.; Goudie, A.S. Geomorphological and palaeoenvironmental investigations in the southeastern Arabian Gulf region and the implication for the archaeology of the region. Geomorphology 2008, 101, 458-470. [CrossRef] 
53. Engel, M.; Brückner, H.; Pint, A.; Wellbrock, K.; Ginau, A.; Voss, P.; Grottker, M.; Klasen, N.; Frenzel, P. The early Holocene humid period in NW Saudi Arabia-Sediments, microfossils and palaeohydrological modelling. Quat. Int. 2012, 266, 131-141. [CrossRef]

54. Matter, A.; Neubert, E.; Preusser, F.; Rosenberg, T.; Al-Wagdani, K. Palaeo-environmental implications derived from lake and sabkha deposits of the southern Rub'al-Khali, Saudi Arabia and Oman. Quat. Int. 2015, 382, 120-131. [CrossRef]

55. Lancaster, N.; Baas, A. Influence of vegetation cover on sand transport by wind: Field studies at Owens Lake, California. Earth Surf. Process. Landf. 1998, 23, 69-82. [CrossRef]

56. Thomas, D.S.G.; Knight, M.; Wiggs, G.F.S. Remobilization of southern African desert dune systems by twenty-first century global warming. Nature 2005, 435, 1218-1221. [CrossRef] [PubMed]

57. Doornkamp, J.C.; Brunsden, D.; Jones, D.K.C. Geology. Geomorphology and Pedologv of Bahrain; Geo. Abstracts Ltd.: Norwich, UK, 1980; p. 443.

(C) 2018 by the authors. Licensee MDPI, Basel, Switzerland. This article is an open access article distributed under the terms and conditions of the Creative Commons Attribution (CC BY) license (http:/ / creativecommons.org/licenses/by/4.0/). 